\title{
Blood parasites in noddies and boobies from Brazilian offshore islands - differences between species and influence of nesting habitat
}

\author{
PETRA QUILLFELDT ${ }^{1 *}$, JAVIER MARTÍNEZ ${ }^{2}$, LEANDRO BUGONI ${ }^{3}$, PATRÍCIA L. \\ MANCINI ${ }^{3}$ and SANTIAGO MERINO \\ ${ }^{1}$ Department of Animal Ecology and Systematics, Fustus Liebig University Giessen, Heinrich-Buff-Ring, 35392 Giessen, \\ Germany \\ ${ }^{2}$ Departamento de Microbiología y Parasitología, Facultad de Farmacia, Universidad de Alcalá de Henares, Alcalá de \\ Henares, E-28871, Madrid, Spain \\ ${ }^{3}$ Universidade Federal do Rio Grande (FURG), Instituto de Ciências Biológicas and Instituto de Oceanografia, Campus \\ Carreiros, CP 474, CEP 96203-900, Rio Grande, RS, Brasil \\ ${ }^{4}$ Departamento de Ecología Evolutiva, Museo Nacional de Ciencias Naturales, Consejo Superior de Investigaciones \\ Cientificas, Madrid, Spain
}

(Received 29 April 2013; revised 14 Fune and 6 August 2013; accepted 19 August 2013; first published online 7 November 2013)

\section{SUMMARY}

Seabirds are often free from blood parasites, and a recent review suggested that phylogenetic, ecological and life-history parameters can determine the prevalence of blood parasites in seabirds. However, there is a lack of data available from many seabird groups, and a larger database is needed to understand prevalence patterns of blood parasites. We used a molecular screening approach to detect parasites of the genera Plasmodium, Haemoproteus, Leucocytozoon and Babesia in five species of two genera of seabirds that breed on Atlantic Ocean islands off Brazil. The observed patterns differed between the two bird genera. Like other Laridae, brown noddy, Anous stolidus adults were infected with Haemoproteus with low prevalence. Masked boobies, Sula dactylatra and brown boobies, Sula leucogaster were infected with Babesia. Of the latter, mainly juveniles were infected. In all species, intensity of infection (i.e. number of infected erythrocytes) was so low that parasites remained undetected in blood smears. This may explain the absence of major effects on the body condition of birds, although infected juvenile masked boobies were lighter than juveniles that were not infected with Babesia. Two tree-nesting species; black noddy, Anous minutus and red-footed booby, Sula sula did not have blood parasites, suggesting that treenesting may reduce the exposure to arthropod vectors compared with ground nesting in these species.

Key words: avian haematozoa, blood parasites, haemoparasites, innate immunity, seabirds.

\section{INTRODUCTION}

Birds are hosts to a number of intracellular blood parasites, including Haemosporidia of the genera Plasmodium, Haemoproteus and Leucocytozoon, Haemogregarinidae of the genus Hepatozoon and piroplasmids of the genus Babesia. These parasites may exert important ecological and evolutionary pressures on life-history traits of avian hosts (e.g. Merino et al. 2000; Hõrak et al. 2001; Marzal et al. 2005).

The prevalence of infection varies greatly among different bird taxa (e.g. Bennett et al. 1993; Valkiūnas 2005). For example, seabirds are often free from blood parasites (e.g. Peirce and Brooke, 1993; Merino et al. 1997a; Merino and Minguez, 1998; Engström et al. 2000). A recent review of blood parasite prevalence in birds suggested that multiple factors are responsible for patterns of association between

* Corresponding author. Department of Animal Ecology and Systematics, Justus Liebig University Giessen, Heinrich-Buff-Ring, 35392 Giessen, Germany. E-mail: petra.quillfeldt@bio.uni-giessen.de parasitic infections and ecological and life history traits in seabirds (Quillfeldt et al. 2011). Indeed, life history and ecological parameters that increase the exposure time to arthropod vectors may be important. Furthermore, historical/phylogenetic factors may also influence susceptibility to different parasitic infections. For example, there is a relatively high prevalence of Haemoproteus in gulls and frigatebirds and Plasmodium in penguins, while Hepatozoon are apparently confined to albatross and storm-petrel species (Quillfeldt et al. 2011).

This study used genetic methods to detect parasites in five species belonging to two genera of seabirds that breed on tropical islands off Brazil. There have been no previous studies in this region that focus on protozoa in seabird blood (Quillfeldt et al. 2011). In particular, we were interested in inter- and intraspecific differences in prevalence patterns of blood parasites in these sympatrically breeding birds. Based on published data, we hypothesized that noddies would most likely be infected with Haemoproteus and boobies with Babesia. 




METHODS

\section{Study sites and species}

Boobies and noddies are circumtropical species that breed yearly. They have mean body masses varying from 100-200 and 800-1500 $\mathrm{g}$ in noddies and boobies, respectively. These seabirds were sampled at five breeding colonies on offshore islands of the Atlantic coast of Brazil (for sample sizes, dates and locations see Tables 1 and 2):

1. Fernando de Noronha $\left(3 \cdot 854^{\circ} \mathrm{S}, 32 \cdot 424^{\circ} \mathrm{W}\right)$ : This site consists of one large island and 19 small adjacent islets, within a total area of $26 \mathrm{~km}^{2}$. It contains the most diverse seabird community in Brazil, with 11 breeding seabird species and c. 25000 breeding pairs (Antas, 1991; Schulz-Neto, 2004a). These islands provide different nesting habitats. For example, black noddies, Anous minutus and red-footed boobies, Sula sula nest in dense (vegetation cover 80\%) forest of the Mulungu tree, Erytrina velutina (Schulz-Neto, 2004a), while brown noddies, Anous stolidus and brown boobies, Sula leucogaster nest on the rocky ground. Masked boobies, Sula dactylatra nest in medium ( $\sim 0.5 \mathrm{~m}$ height) or tall grass $(>0.5 \mathrm{~m}$ height). Arthropods reported on these islands include ticks (IxodidaeRhipicephalus microplus and Astigmatina), flies and mosquitoes (Flechtmann, 1987). Black noddies on Fernando de Noronha also nest in small platforms on the ground of vertical, well-protected cliffs.

2. Abrolhos archipelago $\left(17.926^{\circ} \mathrm{S}, 38.935^{\circ} \mathrm{W}\right)$ is a group of five small islands located $\sim 65 \mathrm{~km}$ off the Brazilian coast. Six seabird species breed at this site, with $c .3000$ breeding pairs (Alves et al. 2000). The percentage of vegetation cover varies between 0 and $40 \%$. Rock, which is sparsely covered with short grass $\sim 0.2 \mathrm{~m}$ high (Alternanthera maritima, Cyperus imbricatus, Blutaparon portulacoides; Hazin and Macedo, 2006) provides nesting habitat for brown noddies, while masked and brown boobies predominantly nest in sites containing tall grass (C. imbricatus, Borreria verticilata; IBAMA/FUNATURA, 1991) as well as short grass. Ticks, mosquitoes and flies (Olfersia spinifera; Graciolli and Carvalho, 2003) have been reported on these islands.

3. Ilha da Trindade $\left(20 \cdot 517^{\circ} \mathrm{S}, 29 \cdot 300^{\circ} \mathrm{W}\right)$ is located at the far east of the Vitória-Trindade submarine ridge, $1160 \mathrm{~km}$ off Brazil. The island has five breeding species, including the brown noddy that nests in areas of large stones, pebbles, bare rock and medium grass (predominantly Cyperus atlanticus and Bulbostylis nesiotis, vegetation cover 40\%). 
Table 2. Studies of blood parasites in boobies, including the present results. The results of PCR-based screening for Babesia are given, and published studies of the same species are summarized (ad. = adults, juv. = juveniles). In the present study, all individuals were negative in PCR-based screening for Plasmodium/

Haemoproteus and Leucocytozoon

\begin{tabular}{|c|c|c|c|c|c|c|}
\hline Species & Site & Date & Adults & Juveniles & Babesia & Reference \\
\hline Red-footed booby & Atol das Rocas & September 2010 & 9 & 16 & - & This study \\
\hline \multirow[t]{8}{*}{ Sula sula } & F. de Noronha & July 2011 & 1 & 0 & - & This study \\
\hline & Total Red-footed booby & (This study) & 10 & 16 & - & This study \\
\hline & Oahu, Hawaii & & 35 & 34 & - & Work (1996) \\
\hline & Aldabra Atoll & & 28 & & - & Lowery (1971) \\
\hline & Genovesa, Galápagos $^{\mathrm{a}}$ & & 23 & & - & Padilla et al. (2006) \\
\hline & Oeno, Pitcairn Islands & & & 15 & - & Peirce and Brooke (1993) \\
\hline & Christmas Island, Indian Ocean ${ }^{\mathrm{b}}$ & & 12 & & - & Quillfeldt et al. (2010) \\
\hline & Total Red-footed booby & (Across studies) & 108 & 65 & - & \\
\hline \multirow{8}{*}{$\begin{array}{l}\text { Masked booby } \\
\text { Sula dactylatra }\end{array}$} & Abrolhos & February 2011 & 30 & 0 & 2 ad. $(6 \cdot 7 \%)$ & This study \\
\hline & & August 2011 & 5 & 17 & 3 juv. $(17 \cdot 6 \%)$ & This study \\
\hline & Atol das Rocas & September 2010 & 31 & 19 & 9 juv. $(47 \cdot 4 \%)$ & This study \\
\hline & F. de Noronha & March 2011 & 31 & 0 & - & This study \\
\hline & & July 2011 & 17 & 18 & 2 ad. $(11 \cdot 8 \%)$ & This study \\
\hline & Total Masked booby & (This study) & 114 & 54 & $\begin{array}{l}4 \text { ad. }(3 \cdot 5 \%) \\
18 \text { juv. }(33 \cdot 3 \%)\end{array}$ & This study \\
\hline & Desnoeufs, Amirantes, Indian Ocean & & & 9 & 2 juv. $(22 \cdot 2 \%)$ & Peirce and Feare (1978) \\
\hline & Total Masked booby & (Across studies) & 114 & 63 & $\begin{array}{l}4 \text { ad. }(3 \cdot 5 \%) \\
20 \text { juv. }(31 \cdot 7 \%)\end{array}$ & \\
\hline \multirow{11}{*}{$\begin{array}{l}\text { Brown booby } \\
\text { Sula leucogaster }\end{array}$} & Abrolhos & February 2011 & 30 & 0 & - & This study \\
\hline & & August 2011 & 10 & 13 & 1 juv. $(7 \cdot 7 \%)$ & This study \\
\hline & SPSPA & August 2010 & 31 & 14 & 1 juv. $(7 \cdot 1 \%)$ & This study \\
\hline & Atol das Rocas & September 2010 & 15 & 15 & 10 juv. $(66 \cdot 7 \%)$ & This study \\
\hline & F. de Noronha & March 2011 & 35 & 7 & - & This study \\
\hline & & July 2011 & 0 & 2 & _- & This study \\
\hline & Total Brown booby & (This study) & 121 & 51 & 12 juv. $(23 \cdot 5 \%)$ & This study \\
\hline & Johnston Atoll & & 70 & 35 & $54 \%$ in chicks, $13 \%$ in adults & Work and Rameyer (1997) \\
\hline & Christmas Island, Indian Ocean ${ }^{\mathrm{b}}$ & & 12 & & - & Quillfeldt et al. (2010) \\
\hline & Offshore islands of northern Mexico & & 1 & & - & Clark and Swinehart (1969) \\
\hline & Total Brown booby & (Across studies) & & & & \\
\hline
\end{tabular}

a $9 \%$ of the Red-footed boobies on Genovesa were infected with Haemoproteus.

b Samples analysed by Quillfeldt et al. (2010) for Plasmodium/Haemoproteus and Leucocytozoon were subsequently also screened for Babesia using the methods outlined in the present paper (Javier Martínez, unpubl. data). 




Flies, O. spinifera have been recorded (Graciolli and Carvalho, 2003), however there are no records of ticks or haematophagous mosquitoes.

4. Atol das Rocas $\left(3.856^{\circ} \mathrm{S}, 33.817^{\circ} \mathrm{W}\right)$ is located $145 \mathrm{~km}$ west of Fernando de Noronha (Kikuchi and Leão, 1997) and has the largest seabird colony with $c .150000$ individuals (Schulz-Neto, 1998), including five seabird species which breed on both islands (Schulz-Neto, 2004b). However, although black noddies and red-footed boobies breed on Fernando de Noronha they also rest and forage on Atol das Rocas (Schulz-Neto, 2004b). These islands are mostly sandy with bushes. Brown noddies, masked and brown boobies nest on the ground, in areas with $80-90 \%$ of short grass vegetation cover, Portulaca oleracea, as well as medium grass, Cyperus ligularis (Schulz-Neto, 2004b). Black noddies breed in coconut palm trees (Cocos nucifera), while red-footed boobies rest in coconut palm trees.

5. The São Pedro and São Paulo Archipelago (SPSPA) $\left(0.917^{\circ} \mathrm{N}, 29.335^{\circ} \mathrm{W}\right)$ is a remote group of 10 small rocky islands located $\sim 1000 \mathrm{~km}$ from the Brazilian coast, and $610 \mathrm{~km}$ from Fernando de Noronha. It contains the smallest colony of seabirds, with three breeding species of approximately 1000 individuals (Both and Freitas, 2004). There is no vegetation on SPSPA, so birds are crowded in a small area of rocky outcrops.

\section{Sample collection and PCR screening}

Chicks and adults were caught either by hand or by using dip nets. Each bird was weighed to the nearest 5 or $10 \mathrm{~g}$ using a Pesola ${ }^{\circledR}$ spring balance. Standard structural measurements were recorded as follows: culmen and tarsus lengths to the nearest $0 \cdot 1 \mathrm{~mm}$ using callipers, wing and tail lengths to the nearest $\mathrm{mm}$ using stopped wing and feather rulers, respectively.

All adults were sampled during the breeding season, while on their nest incubating eggs or attending young, except for black noddies and redfooted boobies, which were sampled at Atol das Rocas, even though they breed on Fernando de Noronha (Schulz-Neto, 2004a, b). Each bird was individually marked with a numbered metal ring to avoid sampling the same bird multiple times. For each bird, a drop of blood was obtained from the tarsal or brachial vein and stored on FTA classic cards (Whatman International Ltd., UK). Small pieces of FTA card were cut with sterilized scissors. Genomic DNA was extracted from FTA cards as indicated by Martínez et al. (2009). Polymerase chain reactions (PCR) were used to detect haemoparasites. Information about primers can be found in Table 3 . 
PCR were performed in a $10 \mu \mathrm{L}$ reaction volume, containing 20-100 ng template DNA, $50 \mathrm{~mm} \mathrm{KCl}$, $10 \mathrm{~mm}$ Tris- $\mathrm{HCl}, 1.5 \mathrm{MgCl}_{2}, 0.2 \mathrm{~mm}$ dNTPs, $0 \cdot 25 \mu \mathrm{M}$ primer, and $1 \cdot 25 \mathrm{U}$ of AmpliTaq Gold 360 (Applied Biosystems, Foster City, CA, USA). PCR using the Veriti thermal cycler (Applied Biosystems, Foster City, CA, USA) conditions are as follows: $95^{\circ} \mathrm{C}$ for $10 \mathrm{~min}$ (polymerase activation), 40 cycles at $95^{\circ} \mathrm{C}$ for $30 \mathrm{~s}$, annealing temperature (see Table 2), extension temperature (see Table 3 ), and a final extension at $72^{\circ} \mathrm{C}$ for $10 \mathrm{~min}$. PCR assays were checked using agarose gel electrophoresis. Amplicons were recovered from agarose gels (UltraClean GelSpin DNA Purification kit, $M O$ BIO) and subjected to direct sequencing using an ABI 3130 (Applied Biosystems) automated sequencer. Positive and negative controls were routinely used.

\section{Phylogenetic analysis}

DNA sequences for Haemoproteus (cytochrome B) obtained from noddies were aligned with 77 other sequences belonging to Haemoproteus or Parahaemoproteus species that can be found on GenBank. The alignment was performed using the CLUSTALW algorithm implemented in BIOEDIT (Hall, 1999). The final alignment contained 558 positions and 80 sequences, including two lineages of Leucocytozoon as the outgroup. The alignments were analysed using Bayesian inference, implemented in MrBayes 3.2 (Ronquist and Huelsenbeck, 2003), setting the substitution model GTR + G. The model was previously selected using corrected AIC (Akaike Information Criterion) implemented in JMODELTEST 0.0.1 (Posada, 2008). This analysis consisted of 2 runs of 4 chains each, with 3000000 generations per run and a burn-in of 300000 generations (54000 trees for consensus tree). The final standard deviation of the split frequencies was lower than $0 \cdot 01$. Convergence was checked using TRACER v1.5 software (a program for analysing the trace files generated by Bayesian MCMC runs; Rambaut and Drummond, 2007). All model parameters were higher than 100 indicating convergence.

The Babesia DNA sequence (18S rDNA) obtained from boobies was aligned together with 20 other sequences belonging to Babesia species that were listed in GenBank. The alignment was performed using PROBCONS (http://toolkit.tuebingen.mpg. de/probcons). Poorly aligned positions and divergent regions of the alignment were suppressed using GBlocks ('Talavera and Castresana, 2007) selecting the following options: 'Minimum Number of Sequences for a Conserved Position' to 11, 'Minimum Number of Sequences for a Flank Position' to 17, 'Maximum Number of Contiguous Nonconserved Positions' to 3, 'Minimum Length of a Block' to 10, and 'Allowed Gap Positions' to
'With Half'. The final alignment contained 1404 positions. In this case, the substitution model $\mathrm{GTR}+\mathrm{I}+\mathrm{G}$ was selected to perform the Bayesian analysis. Only 1000000 generations were necessary to obtain convergence. The tree was rooted on the midpoint.

In addition, the maximum-likelihood inference was also performed using PhyML (Guindon et al. 2010). This analysis was performed with the two alignments. The substitution models were those indicated above, the subtree pruning and regrafting and the nearest-neighbour interchange treerearrangements were selected, and the approximate likelihood-ratio test was used to obtain the clade support.

\section{Microscopic analyses}

Studies using blood smears may not detect parasites if the intensity of infection is low (e.g. Valkiūnas, 2005). Genetic methods using PCR can detect infections missed by blood smears (e.g. Feldman and Freed 1995; Bensch et al. 2000; Perkins and Schall, 2002; Ricklefs et al. 2005; Parker et al. 2006; Merino et al. 2008). PCR has also been shown to be more sensitive than microscopic-based diagnosis of Babesia spp. (Almeria et al. 2001; Ano et al. 2001). However, for identification of the parasite species, molecular methods should be combined with light microscopy (Valkiūnas et al. 2008).

A drop of blood from each bird was immediately smeared and air-dried, fixed with methanol and later stained with Giemsa stain $(1 / 10 \mathrm{v} / \mathrm{v})$ for $30 \mathrm{~min}$. Blood smears from birds that were positive for blood parasite infections by PCR were scanned using an optic microscope following methods described by Merino et al. (1997b). In brief, one-half of every blood smear was scanned at $\times 200$ to look for extracellular parasites. Intracellular stages of haematozoa were sought at $\times 400$ in the other half of the sample. The oil immersion objective was used when a possible parasite was sought at $\times 400$. All samples were scanned using a microscope Olympus B061.

\section{Statistical data analysis}

Statistical analyses were carried out in SigmaStat 3.5. and SPSS 11.0. Prevalence was given with 95\% confidence intervals $(95 \% \mathrm{CI})$. In order to compare the body condition of birds infected or free from parasites, and among birds of archipelagos with different rates of infection, we calculated mass residuals, i.e. the difference between observed mass and predicted mass. Predicted masses were calculated using a linear regression of body mass on four measures of structural size (e.g. Dehnhard et al. 2011). To account for temporal changes in body mass, only birds sampled in August-September were 
included in these analyses. Predicted masses were calculated for brown noddy adults according to the regression equation: $M_{\text {mean }}=-330 \cdot 9+1 \cdot 4 *$ Culmen $+3 \cdot 2 *$ Tarsus $+1 \cdot 2 *$ Wing $+0 \cdot 3 *$ Tail $\quad(R=$ $0.597, \quad F=9 \cdot 3, \quad P<0 \cdot 001)$. The calculated mass residuals were compared among birds of the different archipelagos using analysis of variance (ANOVA). Predicted masses for juvenile masked boobies were calculated according to the regression equation: $\quad M_{\text {mean }}=-2278 \cdot 2+17 \cdot 1 * \quad$ Culmen + $27 \cdot 8 *$ Tarsus $-0 \cdot 9 *$ Wing $+5 \cdot 3 *$ Tail $\quad(R=0 \cdot 612$, $F=7 \cdot 3, P<0 \cdot 001)$. The calculated mass residuals were compared among individuals with and without parasites using $t$-tests.

\section{RESULTS}

\section{Noddies}

We did not detect any parasites in black noddies $(N=34$ adults and 8 juveniles, Table 1$)$. In brown noddies, 8 of 98 adult birds $(8 \cdot 2 \pm 5 \cdot 4 \%)$ were infected with Haemoproteus (GenBank accession number KC754967), while none of the juveniles $(N=73)$ were infected. Haemoproteus DNA was detected in adult brown noddies from two of five sampling sites (Table 1), namely a high prevalence on SPSPA $(30 \cdot 4 \pm 18 \cdot 8 \%, \mathrm{~N}=23)$ and a single bird at Atol das Rocas $(2 \cdot 9 \pm 5 \cdot 5 \%, N=35)$. The proportions of infected adult brown noddies varied among colonies (Chi-square test: $\chi^{2}=20 \cdot 1$, D.F. $=4, P<0 \cdot 001$ ). The mass residuals of adult brown noddies did not differ among archipelagos with different occurrence of Haemoproteus (ANOVA: $F_{2,69}=1 \cdot 4, P=0 \cdot 248$ ). We did not detect parasites from blood smears, indicating a low intensity of infection.

The phylogenetic analysis showed that the haplotype 288 isolated from noddies clustered with three Haemoproteus haplotypes isolated from other seabirds (Fig. 1), of which Haemoproteus jenniae isolated from swallow-tailed gulls (Creagrus furcatus) was the closest species (99.5\%). The genetic distance between haplotype 288 and Haemoproteus iwa isolated from magnificent frigatebird Fregata magnificens was 1·3\%.

\section{Boobies}

We did not detect any parasites in red-footed boobies $(N=10$ adults and 16 juveniles, Fig. 2, Table 2). Brown boobies and masked boobies were infected with Babesia (GenBank accession number KC754965).

In brown boobies, only juveniles were infected $(23 \cdot 5 \pm 11 \cdot 6 \%, N=51)$, while all adults $(N=121)$ were free from blood parasites. Babesia DNA was detected in brown booby juveniles from three of four breeding sites (Table 2), with low prevalence on Abrolhos $(7 \cdot 7 \pm 14 \cdot 5 \%, N=13)$ and SPSPA $(7 \cdot 1 \pm 13 \cdot 5 \%$. $N=14)$, but high prevalence in the largest colony, on Atol das Rocas (66.7 $\pm 23 \cdot 9 \%$, $N=15)$. The proportions of infected brown booby juveniles varied among colonies $\left(\chi^{2}=22 \cdot 2\right.$, D.F. $=3$, $P<0 \cdot 001)$. However, brown booby juveniles from archipelagos with different occurrence of Babesia did not differ in their mass residuals (ANOVA: $F_{2,36}=0 \cdot 2, P=0 \cdot 830$ ). Likewise, the mass residuals were similar between brown booby juveniles whether infected or free of Babesia ( $t$-test: $t=0 \cdot 2$, D.F. $=37$, $P=0 \cdot 824)$.

In masked boobies, the prevalence was nearly ten times higher in juveniles $(33 \cdot 3 \pm 12 \cdot 6 \%, N=54)$ than in adults $(3 \cdot 5 \pm 3 \cdot 4 \%, N=114)$. The difference in prevalence between adults and juveniles was statistically significant $\left(\chi^{2}=26 \cdot 1, \quad\right.$ D.F. $\left.=1, \quad P<0 \cdot 001\right)$. Adults were infected in two of three colonies, with low prevalences of $5 \cdot 7 \pm 7 \cdot 7 \%$ at Abrolhos $(N=35)$ and $4 \cdot 2 \pm 5 \cdot 7 \%$ at Fernando de Noronha $(N=48)$. Juveniles were infected at all three breeding sites, with intermediate to high prevalence of $17 \cdot 6 \pm 18 \cdot 1 \% \quad$ (Abrolhos, $\quad N=17$ ),$\quad 33 \cdot 3 \pm 21 \cdot 8 \%$ (Fernando de Noronha, $N=18$ ) and $47 \cdot 4 \pm 22 \cdot 5 \%$ (Atol das Rocas, $N=19$ ). The proportions of infected masked boobies did not vary significantly among colonies for either adults $\left(\chi^{2}=1 \cdot 7\right.$, D.F. $=2$, $P=0 \cdot 429$, power $0 \cdot 18)$ or juveniles $\left(\chi^{2}=3 \cdot 6\right.$, D.F. $=2$, $P=0 \cdot 168$, power $0 \cdot 36$ ).

We did not detect parasites from blood smears, indicating the low intensity of infection. However, masked booby juveniles infected with Babesia were on average $74 \cdot 1 \pm 44 \cdot 6 \mathrm{~g}$ lighter than the population mean, while uninfected masked booby juveniles were on average $37 \cdot 0 \pm 28 \cdot 6 \mathrm{~g}$ heavier than the population mean. This difference of $c$. $7 \%$ of body mass was statistically significant $(t$-test: $t=2 \cdot 2, \quad$ D.F. $=52$, $P=0 \cdot 034)$.

Phylogenetic analysis showed that the haplotype 211 isolated from boobies clustered with two Babesia haplotypes isolates from seabirds, Babesia poelea from brown booby and Babesia sp. from common murre Uria aalge (Fig. 3). The genetic distance between these Babesia species and the haplotype 211 was 0.3 and $0 \cdot 8 \%$, respectively. However, other Babesia species (Babesia kiwiensis and Babesia bennetti) isolated from birds were phylogenetically distant from this clade.

\section{DISCUSSION}

In accordance with other seabird studies (reviewed by Quillfeldt et al. 2011), parasite prevalences were low in five species of tropical Brazilian seabirds from Atlantic Ocean islands. Two species were free from parasites, and the other three species had low blood parasite prevalences with parasites detected being the typically found parasite taxa for each genus, with no multiple infections. The absence of infections in black noddies and red-footed boobies might be explained by their different nesting 


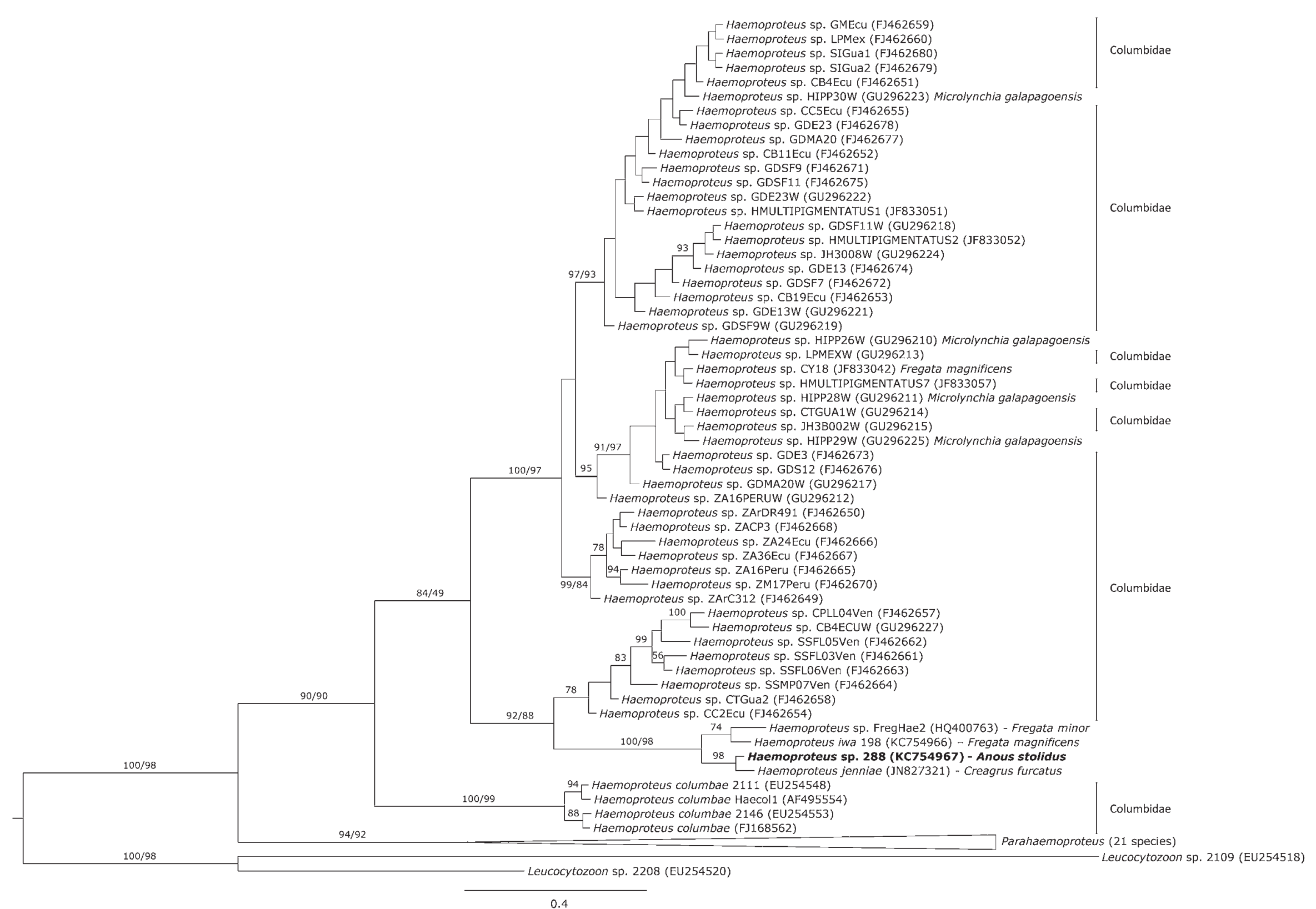

Fig. 1. Phylogenetic inference of the Haemoproteus haplotype found in brown noddies Anous stolidus. Phylogenetic tree was obtained with the program MrBayes v3.2 using the substitution model GTR $+\mathrm{G}$. When clades present two support values, the first one corresponds with the Bayesian support and the second one with that achieved by maximum likelihood inference. The Haemoproteus haplotype isolated in the present study is marked in bold. 
Sula dactylatra
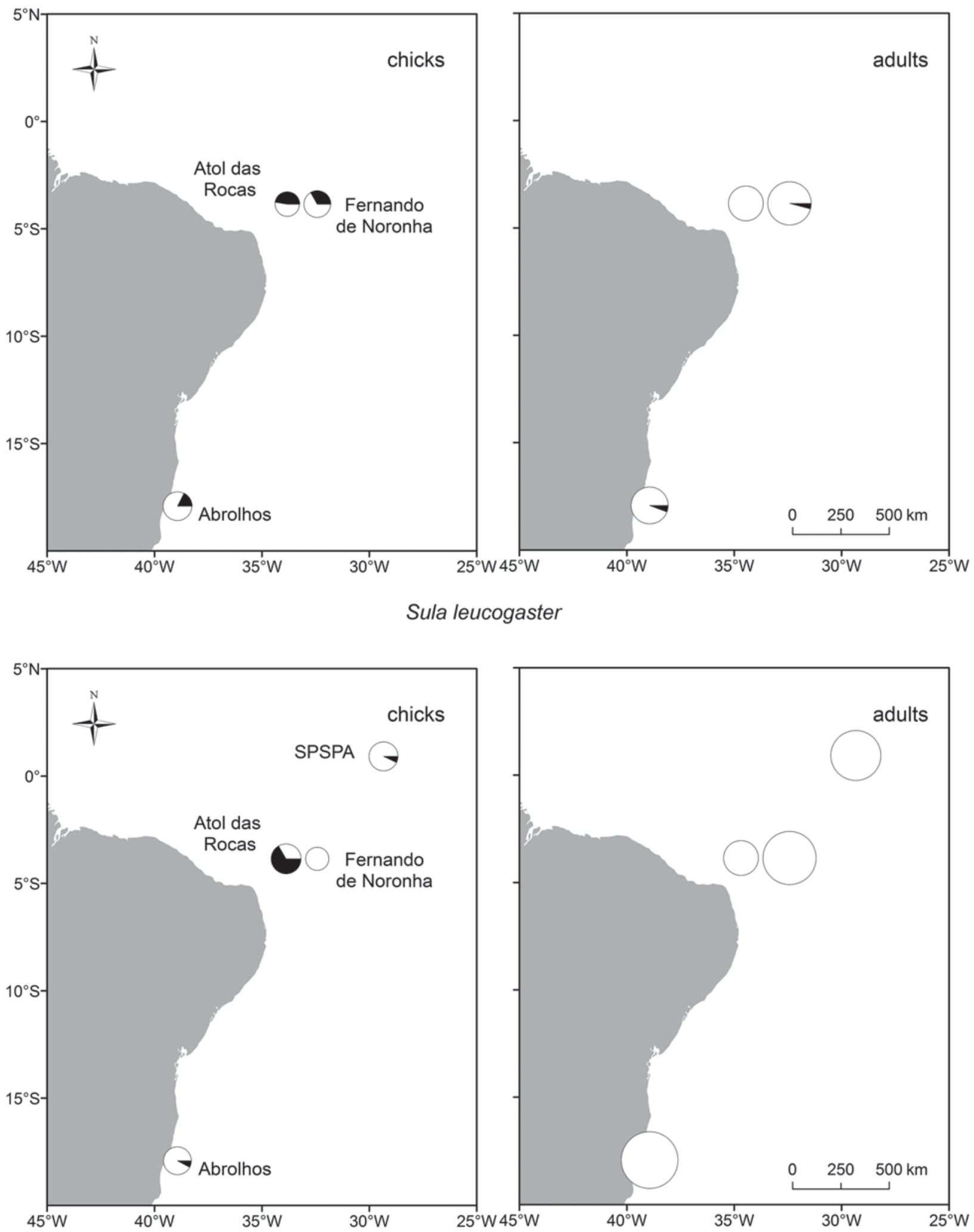

Fig. 2. Infection of brown and masked boobies with Babesia poelea on Brazilian Atlantic islands. The size of the symbols represents the sample size, and the portion of black in the circle represents the percentage of infected animals.

habitats. In contrast to ground-nesting species, these two species nest on trees or bushes, where louse flies (Hippoboscidae), common vectors for
Haemoproteus, and ticks (Ixodidae), common vectors for Babesia (e.g. Smith, 1996), may be less likely to occur. 


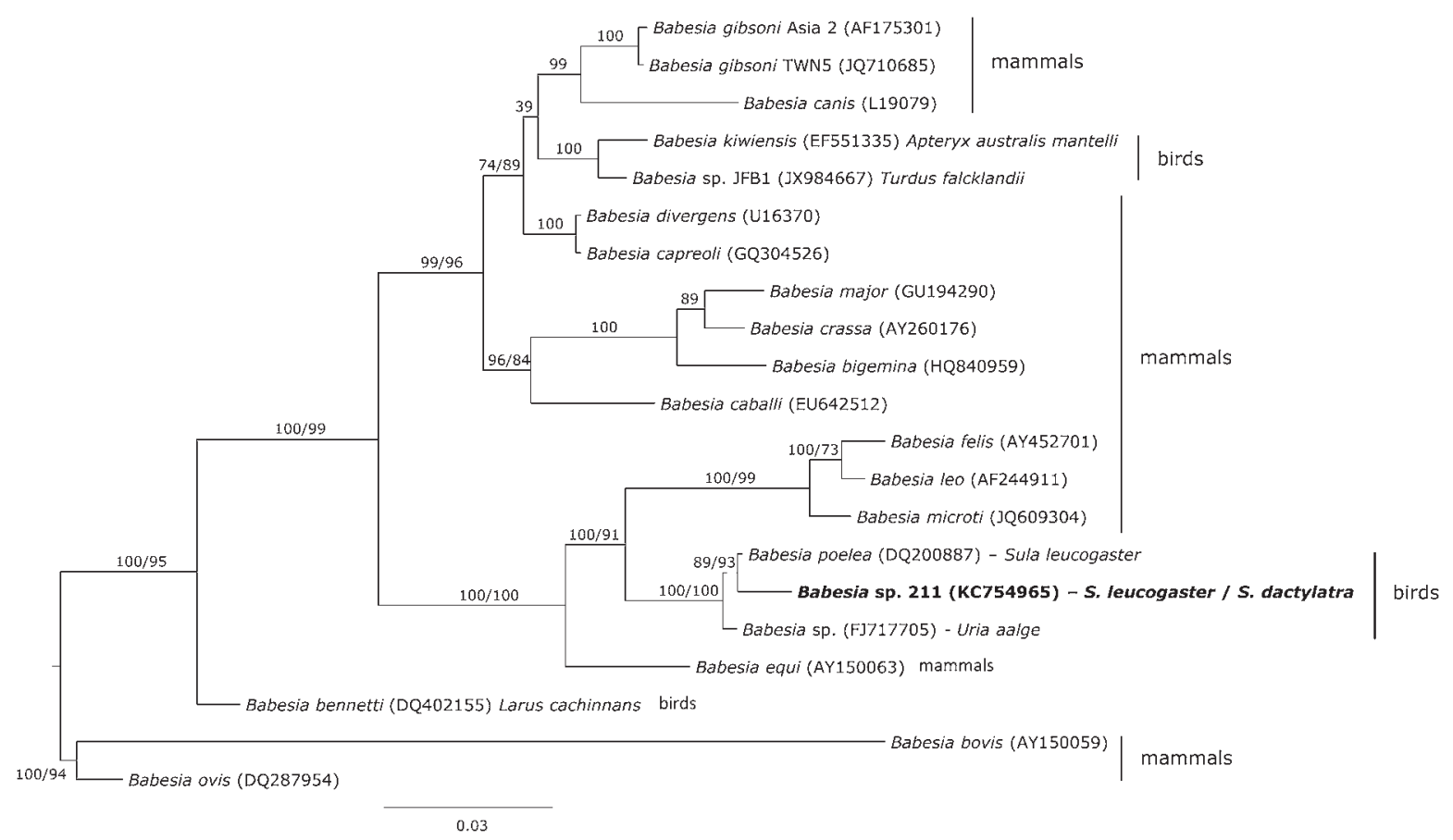

Fig. 3. Phylogenetic inference of the Babesia haplotype found in brown and masked boobies. Phylogenetic tree was obtained with the program MrBayes v3.2 using the substitution model GTR + I + G. When clades present two support values, the first one corresponds with the Bayesian support and the second one with that achieved by maximum likelihood inference. The Babesia haplotype isolated in the present study is marked in bold.

\section{Noddies as hosts of Haemoproteus}

Haemoproteus sp. are globally distributed in birds with about 100 named species (Peirce, 2005). Within seabirds, Haemoproteus parasites are especially common in frigatebirds, Fregatidae (Quillfeldt et al. 2011; Merino et al. 2012) and gulls and terns, Laridae (Quillfeldt et al. 2011).

Thus, our present finding of a Haemoproteus infection in a noddy, belonging to, or with close affinity to the Laridae, supports this pattern. The only previous record of a Haemoproteus infection in a noddy was detected on Aldabra Atoll in the Indian Ocean, where one of 24 adult brown noddies was infected by an unknown species of Haemoproteus (Lowery, 1971). The phylogenetic analysis showed that the Haemoproteus haplotype isolated from noddies on Brazilian islands are close to others isolated from seabirds including gulls. The lack of haematic stages in the blood smears indicated that the infection was chronic and not acute (e.g. Madsen et al. 2007). The fact that only adult individuals were found parasitized further suggested that risk of infection is related to their permanence in areas inhabited by suitable vectors.

In general, Haemoproteus parasites are considered relatively benign in birds. Two seabird species affected by Haemoproteus have been studied in detail, through correlative analyses. In magnificent frigatebirds, $16 \%$ of males were infected with $H$. iwa, but all infections were light $(<1 \%$ of erythrocytes) and were thus classified as chronic (Madsen et al. 2007). In yellow-legged gulls, Larus cachinnans, MartínezAbraín et al. (2002) found significant differences in Haemoproteus lari prevalence between two breeding colonies, which were explained with differences in the vector abundance. The birds of both colonies were in equally good body condition and had similar clutch sizes. Further, the intensity of $H$. lari infection was not correlated with body condition or egg volume (Martínez-Abraín et al. 2002), suggesting that H. lari parasites had little effect on the health of the gulls under normal conditions.

Likewise, Haemoproteus infection in the present study was not correlated to the body condition of noddies. Studies in other birds also suggest that Haemoproteus numbers are normally kept low by natural immunity and only tend to multiply under stress and other diseases. It has therefore been suggested that increasing Haemoproteus parasitaemia (percentage of red cells infected) can serve as a valuable indicator of an underlying disease (e.g. Remple, 2004) or of stress (Valkiūnas, 2005). However, experimental studies suggest important detrimental effects of Haemoproteus blood parasites on bird fitness (Merino et al. 2000; Marzal et al. 2005). In magnificent frigatebirds, males infected with $H$. iwa had a less intensely coloured red inflatable gular pouch (Madsen et al. 2007), which is an important ornament used in mate choice (Dearborn et al. 2001). This suggests that even light infections can influence the reproductive success 
of individuals and thus, be subject to intense selection.

\section{Boobies as hosts of $\mathrm{B}$. poelea}

Babesia spp. are tick-transmitted protozoan haemoparasites that infect mammals and birds. Currently, over 100 Babesia species are known, and together with Theileria spp. they are referred to as piroplasmids or piroplasms (Piroplasmida). Of 14-18 Babesia species recognized in birds (Jefferies et al. 2008; Votýpka, 2011; Peirce and Parsons, 2012), five infect different seabird groups: B. poelea (boobies), Babesia peircei (2 penguin species), B. bennetti (1 gull species), Babesia uriae (1 auk species) and Babesia ugwidiensis (5 cormorant species). While the majority of species infecting domestic mammals cause disease, only two avian species, Babesia shortti and B. uriae, are known to be pathogenic (Samour and Peirce, 1996; Yabsley et al. 2009; Votýpka, 2011).

Babesia had been found previously in two studies in boobies (Table 2). The first record applied to two of nine nestling masked boobies $(22 \%)$ that were infected at Desnoeufs, Amirantes, Western Indian Ocean (Peirce and Feare, 1978), and B. poelea that was then described in Brown Boobies at Johnston Atoll (Work and Rameyer, 1997). There, B. poelea was found in blood smears from $54 \%$ of the chicks, and $13 \%$ of the adults. While the prevalence was high, mean parasitaemia in adults and chicks was less than $1 \%$ (Work and Rameyer, 1997), similar to our findings. Babesia infection in the present study was not correlated to the body condition of brown booby juveniles, but masked booby juveniles with a Babesia infection were lighter than those not infected, indicating a slight effect on the health of these birds.

It has been established that once birds become infected with haemosporidian parasites, they remain infected either for life or many years (Garnham, 1966; Valkiūnas, 2005), with infections tending to be dynamic, with relapses occurring. In contrast, juveniles in our study were more susceptible to Babesia infections than adults, and infections apparently decrease in intensity or disappear with increasing age and acquisition of immunity. A higher prevalence of infection in chicks also had been noted in previous studies in boobies (Work and Rameyer, 1997). Similarly, $20 \%$ of juvenile prairie falcons Falco mexicanus were infected with Babesia moshkovskii (Croft and Kingston, 1975) and Babesia infections in birds are commonly reported from undernourished young individuals (see Merino, 1998; Peirce, 2000; Merino et al. 2002). Boobies and other birds would therefore make interesting models to study mechanisms of condition- or age-related acquired immunity.

Babesia poelea was originally described as an endemic avian haemoparasite in seabirds from the central Pacific (Work and Rameyer, 1997). The Babesia haplotype isolated in the present study was closely related with $B$. poelea, the genetic distance between them being $0 \cdot 3 \%$. Furthermore, the lack of haematic stages in the smears does not make it possible to identify the species. Peirce (2000) suggested that $B$. peircei could be a synonym of $B$. poelea and a molecular study is currently being conducted to solve this problem (see Peirce and Parsons, 2012). The result of the latter study could also help to identify the Babesia species reported here. However, the most relevant issue achieved from the phylogenetic analysis was the lack of monophyly for avian Babesia, as previously reported by Yabsley et al. (2009).

The Babesia life cycle typically consists of a sexual phase that takes place in Ixodid ticks, and asexual reproduction inside erythrocytes of vertebrate hosts (Schnittger et al. 2012 and references therein). Given the abundance of Ixodid ticks in many seabird colonies, the scarcity of piroplasms is surprising. However, the avian piroplasms remain an understudied group of protozoans (Jefferies et al. 2008), and targeted studies are expected to uncover more avian piroplasms in the future and also to resolve the current taxonomic confusion. There is also debate whether Babesia species are highly adapted to specific vertebrate hosts. Most species of Babesia infecting mammals or birds are host-specific at least to the family level (Votýpka, 2011). However, some recent studies suggest relatively low host specificity and host switching, such as occasional human infections by Babesia microti, B. divergens, B. duncani (see also Criado et al. 2006; Yabsley and Shock, 2013). In the present study, sympatrically breeding seabirds such as noddies were not infected with Babesia, while boobies were infected with $B$. poelea in far separated sites in the Pacific as well as the Atlantic, thus suggesting high host specificity of this piroplasm.

\section{ACKNOWLEDGEMENTS}

We would like to thank Felipe M. Neves, Fernanda P. Marques, Guilherme T. Nunes and Luciana R. Camillo for assistance in the field and Carlos San Juan Martín for assistance in the laboratory.

Fieldwork was supported by Zelinha Brito Silva (Reserva Biológica do Atol das Rocas, ICMBio/RN, Brazil), Ricardo Jerozolimski (Parque Nacional Marinho de Abrolhos ICMBio/BA, Brazil), Ricardo Araújo (Parque Nacional Marinho de Fernando de Noronha ICMBio/PE, Brazil) and Corpo de Bombeiros de Pernambuco from Fernando de Noronha archipelago for permits and logistical support. Brazilian Navy and Comissão Interministerial para os Recursos do Mar (CIRM/SECIRM) provided logistic support for the Trindade and SPSPA expeditions. Also we thank ICMBio for sampling permit No. 22697-1 and CEMAVE-ICMBio for providing us banding permit and leg bands.

F I NANCIAL S UPPORT

During the preparation of this work, JM and SM were supported by project CGL2009-09439 from the Spanish 
Ministry of Science and Technology, and PQ by a grant from DFG, Germany (Qu 148/1-ff). The Brazilian Research Council (CNPq-Grant No. 557152/2009-7) funded the project. PLM was supported by CAPES Foundation (Grant No. 9733/2011-6). LB is a research fellow from the Brazilian CNPq (Proc. No. 308697/2012-0). We thank two anonymous referees for useful comments and Tess Cole for revising the English during the review stage.

\section{REFERENCES}

Almeria, S., Castella, J., Ferrer, D., Ortuno, A., Estrada-Pena, A. and Gutierrez, J. F. (2001). Bovine piroplasms in Minorca (Balearic Islands, Spain): a comparison of PCR-based and light microscopy detection. Veterinary Parasitology 99, 249-259.

Alves, V. S., Couto, G. S., Efe, M. A. and Ribeiro, A. B. B. (2000). As aves do Arquipélago dos Abrolhos. Ibama, Brasília, Brazil.

Ano, H., Makimura, S. and Harasawa, R. (2001). Detection of Babesia species from infected dog blood by polymerase chain reaction. Fournal of Veterinary Medical Science 63, 111-113.

Antas, P. T.Z. (1991). Status and conservation of seabirds breeding in Brazilian waters. In Seabird Status and Conservation: A Supplement (Techn. Publ. 11) (ed. Croxall, J. P.), pp. 141-158. International Council for Bird Preservation, Cambridge, UK.

Atkinson, C. T., Utzurrum, R. C., Seamon, J. O., Savage, A. F. and Lapointe, D. A. (2006). Hematozoa of forest birds in American Samoa-evidence for a diverse, indigenous parasite fauna from the South Pacific. Pacific Conservation Biology 12, 229.

Bennett, G. F., Bishop, M. A. and Peirce, M. A. (1993). Checklist of the avian species of Plasmodium Marchiafava and Celli, 1885 (Apicomplexa) and their distribution by avian family and Wallacean life zones. Systematic Parasitology 26, 171-179.

Bensch, S., Stjernman, M., Hasselquist, D., Ostman, O., Hansson, B., Westerdahl, H. and Pinheiro, R. T. (2000). Host specificity in avian blood parasites: a study of Plasmodium and Haemoproteus mitochondrial DNA amplified from birds. Proceedings of the Royal Society of London B, Biological Sciences 267, 1583-1589.

Both, R. and Freitas, T. O. R. (2004). Aves marinhas no arquipélago de São Pedro e São Paulo. In Aves marinhas e insulares brasileiras: bioecologia e conservação (ed. Branco, J. O.), pp. 193-212. Editora da UNIVALI, Itajá, Brazil.

Clark, G. W. and Swinehart, B. (1969). Avian haematozoa from the offshore islands of northern Mexico. Fournal of Wildlife Diseases 5, 111-112. Criado, A., Martínez, J., Buling, A., Barba, J.C., Merino, S., Jefferies, R. and Irwin, P. J. (2006). New data on epizootiology and genetics of piroplasms based on sequences of small ribosomal subunit and cytochrome b genes. Veterinary Parasitology 142, 238-247.

Croft, R. E. and Kingston, N. (1975). Babesia moshkovskii (Schuren-kova, 1938) Laird and Lari, 1957; from the prairie falcon, Falco mexicanus, in Wyoming; with comments on other parasites found in this host. Fournal of Wildife Diseases 11, 229-233.

Dearborn, D. C., Anders, A. D. and Parker, P. G. (2001). Sexual dimorphism, extrapair fertilizations, and operational sex ratio in great frigatebirds (Fregata minor). Behavioral Ecology 12, 746-752.

Dehnhard, N., Quillfeldt, P. and Hennicke, J.C. (2011). Leucocyte profiles and $\mathrm{H} / \mathrm{L}$ ratios in chicks of red-tailed tropicbirds reflect the ontogeny of the immune system. Fournal of Comparative Physiology B 181, $641-648$

Engström, H., Dufva, R. and Olsson, G. (2000). Absence of haematozoa and ectoparasites in a highly sexually ornamented species, the crested auklet. Waterbirds 23, 486-488

Feldman, R. A. and Freed, L. A. (1995). A PCR test for avian malaria in Hawaiian birds. Molecular Ecology 4, 663-674.

Flechtmann, C. H.W. (1987). Sobre uma pequena coleção de ácaros (Arthropoda, Acari) do território federal de Fernando de Noronha, Brasil. Anais da Escola Superior de Agricultura Luiz de Queiroz 44, 1643-1647.

Garnham, P. C. C. (1966). Malaria Parasites and other Haemosporidia. Blackwell, Oxford, UK.

Graciolli, G. and Carvalho, C. J. B. (2003). Hippoboscidae (Diptera, Hippoboscoidea) no Estado do Paraná, Brasil: chaves de identificação, hospedeiros e distribuição geográfica. Revista Brasileira de Ornitologia 20, $667-674$

Guindon, S., Dufayard, J. F., Lefort, V., Anisimova, M., Hordijk, W. and Gascuel, O. (2010). New algorithms and methods to estimate maximum-likelihood phylogenies: assessing the performance of PhyML 3.0. Systematic Biology 59, 307-321
Hall, T. A. (1999). BioEdit: a user-friendly biological sequence alignment editor and analysis program for Windows 95/98/NT. Nucleic Acids Symposium Series 41, 95-98.

Hazin, M. C. and Macedo, R. H. (2006). Sooty tern nesting success as a function of nest location, density and vegetation type in a Neotropical atoll. Revista Brasileira de Ornitologia 14, 261-268.

Hõrak, P., Ots, I., Vellau, H., Spottiswoode, C. and Møller, A.P. (2001). Carotenoid-based plumage coloration reflects hemoparasite infection and local survival in breeding great tits. Oecologia 126, 166-173.

IBAMA/FUNATURA (1991). Plano de Manejo do Parque Nacional Marinho dos Abrolhos, pp. 96. Instituto Brasileiro do Meio Ambiente e dos Recursos Naturais Renováveis/Fundação Pró Natureza, Brasília. Aracruz Celulose S.A.

Jefferies, R., Down, J., McInnes, L., Ryan, U., Robertson, H., Jakob-Hoff, R. and Irwin, P. (2008). Molecular characterization of Babesia kiwiensis from the brown kiwi (Apteryx mantelli). Yournal of Parasitology 94, 557-560.

Kikuchi, R. K.P. and Leão, Z.M. A. N. (1997). Rocas (Southwestern Equatorial Atlantic, Brazil): an atoll built primarily by coralline algae. Proceedings of the 8th International Coral Reef Symposium 1, 731-736.

Lowery, R. S. (1971). Blood parasites of vertebrates on Aldabra. Philosophical Transactions of the Royal Society of London B 260, 577-580. Madsen, V., Valkiūnas, G., Iezhova, T. A., Mercade, C., Sanchez, M. and Osorno, J. L. (2007). Testosterone levels and gular pouch coloration in courting magnificent frigatebird (Fregata magnificens): variation with ageclass, visited status and blood parasite infection. Hormones and Behavior 51, 156-163.

Martínez, J., Martínez de la Puente, J., Herrero, J., Del Cerro, S., Lobato, E., Rivero de Aguilar, J., Vasquez, R. A. and Merino, S. (2009). A restriction site to differentiate Plasmodium and Haemoproteus infections in birds: on the inefficiency of general primers for detection of mixed infections. Parasitology 136, 713-722.

Martínez-Abraín, A., Merino, S., Oro, D. and Esparza, B. (2002) Prevalence of blood parasites in two western-Mediterranean local populations of the yellow-legged gull Larus cachinnans michahellis. Ornis Fennica 79, 34-40

Marzal, A., de Lope, F., Navarro, C. and Møller, A. P. (2005). Malarial parasites decrease reproductive success: an experimental study in a passerine bird. Oecologia 142, 541-545.

Merino, S. (1998). Babesia bennetti sp. nov., from the yellow-legged gull (Larus cachinnans, Aves, Laridae) in Benidorm Island, Mediterranean sea. Fournal of Parasitology 84, 422-424.

Merino, S. and Minguez, E. (1998). Absence of hematozoa in a breeding colony of the storm petrel Hydrobates pelagicus. Ibis 140, 180-181.

Merino, S., Barbosa, A., Moreno, J. and Potti, J. (1997a). Absence of haematozoa in a wild chinstrap penguin Pygoscelis antarctica population. Polar Biology 18, 227-228.

Merino, S., Potti, J. and Fargallo, J. A. (1997b). Blood parasites of some passerine birds from central Spain. Yournal of Wildlife Diseases 33, 638-641.

Merino, S., Moreno, J., Sanz, J. J. and Arriero, E. (2000). Are avian blood parasites pathogenic in the wild? A medication experiment in blue tits (Parus caeruleus). Proceedings of the Royal Society of London B, Biological Sciences 267, 2507-2510.

Merino, S., Peirce, M. A., Fernández, M. and Lanzarot, P. (2002). Redescription of Babesia moshkovskii (Schurenkova) from the griffon vulture Gyps fulvus (Hablizl). Yournal of Natural History 36, 1635-1638.

Merino, S., Martinez, J., Martinez-de la Puente, J., CriadoFornelio, A., Tomas, G., Morales, J., Lobato, E. and GarciaFraile, S. (2006). Molecular characterization of the 18S rDNA gene of an avian Hepatozoon reveals that it is closely related to Lankesterella. Fournal of Parasitology 92, 1330-1335.

Merino, S., Moreno, J., Vásquez, R. A., Martínez, J., SánchezMonsálvez, I., Estades, C.F., Ippi, S., Sabat, P., Rozzi, R. and McGehee, S. (2008). Haematozoa in forest birds from southern Chile: latitudinal gradients in prevalence and parasite lineage richness. Austral Ecology 33, 329-340.

Merino, S., Hennicke, J., Martínez, J., Ludynia, K., Masello, J. F. and Quillfeldt, P. (2012). Infection by Haemoproteus parasites in four species of frigatebirds and description of Haemoproteus (Parahaemoproteus) valkiūnasi sp. nov. (Haemosporida, Haemoproteidae). Fournal of Parasitology 98, 388397

Padilla, L. R., Whiteman, N. K., Merkel, J., Huyvert, K.P. and Parker, P. G. (2006). Health assessment of seabirds on Isla Genovesa, Galápagos. Ornithological Monographs 60, 86-97.

Parker, P. G., Whiteman, N. K. and Miller, R. E. (2006). Conservation medicine on the Galápagos islands: partnerships among behavioral, population, and veterinary scientists. $A u k 123,625-638$. 
Peirce, M. A. (2000). A taxonomic review of avian piroplasms of the genus Babesia Starcovici, 1893 (Apicomplexa: Piroplasmorida: Babesiidae). Fournal of Natural History 34, 317-332.

Peirce, M. A. (2005). A checklist of the valid avian species of Babesia (Apicomplexa: Piroplasmorida), Haemoproteus, Leucocytozoon (Apicomplexa: Haemosporida), and Hepatozoon (Apicomplexa: Haemogregarinidae). Fournal of Natural History 39, 3621-3632.

Peirce, M. A. and Feare, C. J. (1978). Piroplasmosis in the masked booby Sula dactylatra melanops in the Amirantes, Indian Ocean. Bulletin of the British Ornithologists' Club 98, 38-40.

Peirce, M. A. and Brooke, M. (1993). Failure to detect blood parasites in seabirds from the Pitcairn Islands. Seabird 15, 72-74.

Peirce, M. A. and Parsons, N. J. (2012). Babesia ugwidiensis, a new species of avian piroplasm from Phalacrocoracidae in South Africa. Parasite 19 375-379.

Perkins, S. L. and Schall, J. J. (2002). A molecular phylogeny of malarial parasites recovered from cytochrome b gene sequences. Fournal of Parasitology 88, 972-978.

Posada, D. (2008). jModelTest: phylogenetic model averaging. Molecular Biology and Evolution 25, 1253-1256.

Quillfeldt, P., Martinez, J., Hennicke, J., Ludynia, K., Gladbach, A., Masello, J.F., Riou, S. and Merino, S. (2010) Hemosporidian blood parasites in seabirds - a comparative genetic study of species from Antarctic to tropical habitats. Naturwissenschaften 97, 809-817.

Quillfeldt, P., Arriero, E., Martínez, J., Masello, J. F. and Merino, S. (2011). Prevalence of blood parasites in seabirds - a review. Frontiers in Zoology 8, 26

Rambaut, A. and Drummond, A. J. (2007). Tracer v1.4. Institute of Evolutionary Biology, University of Edinburgh. http://beast.bio.ed.ac.uk/ Tracer

Remple, J. D. (2004). Intracellular hematozoa of raptors: a review and update. Fournal of Avian Medicine and Surgery 18, 75-88.

Ricklefs, R. E. and Fallon, S. M. (2002). Diversification and hos switching in avian malaria parasites. Proceedings of the Royal Society of London B, Biological Sciences 269, 885-892.

Ricklefs, R. E., Swanson, B. L., Fallon, S. M., Martinez-Abrain, A. Scheuerlein, A., Gray, J. and Latta, S. C. (2005). Community relationships of avian malaria parasites in southern Missouri. Ecological Monographs 75, 543-555.

Ronquist, F. and Huelsenbeck, J. P. (2003). MrBayes 3: Bayesian phylogenetic inference under mixed models. Bioinformatics 19, 1572-1574.
Samour, J. H. and Peirce, M. A. (1996). Babesia shortti infection in a saker falcon (Falco cherrug). Veterinary Record 139, 167-168.

Schnittger, L., Rodriguez, A.E., Florin-Christensen, M. and Morrison, D. A. (2012). Babesia: a world emerging. Infection, Genetics and Evolution 12, 1788-1809.

Schulz-Neto, A. (1998). Aspectos biológicos da avifauna na Reserva Biológica do Atol das Rocas, Rio Grande do Norte, Brasil. Hornero 15, 17-28.

Schulz-Neto, A. (2004a). Aves insulares do arquipélago de Fernando de Noronha. In Aves marinhas e insulares brasileiras: bioecologia e conservação (ed. Branco, J. O.), pp. 147-168. Univali, Itajaí.

Schulz-Neto, A. (2004b). Aves marinhas do Atol das Rocas. In Aves marinhas e insulares brasileiras: bioecologia e conservação (ed. Branco, J. O.), pp. 169-192. Univali, Itajaí

Smith, T. G. (1996). The genus Hepatozoon (Apicomplexa: Adeleina) Fournal of Parasitology 82, 565-585.

Talavera, G. and Castresana, J. (2007). Improvement of phylogenies after removing divergent and ambiguously aligned blocks from protein sequence alignments. Systematic Biology 56, 564-577.

Valkiūnas, G. (2005). Avian Malaria Parasites and other Haemosporidia. CRC Press, Boca Raton, FL, USA

Valkiūnas, G., Iezhova, T. A., Krizanauskiene, A., Palinauskas, V., Seghal, R. N. M. and Bensch, S. (2008). A comparative analysis of microscopy and PCR-based detection methods for blood parasites. Fournal of Parasitology 94, 1395-1401.

Votýpka, J. (2011). Babesia. http://tolweb.org/Babesia/68087/2011.05.18 in The Tree of Life Web Project. http://tolweb.org/

Work, T.M. (1996). Weight, hematology, and serum chemistry of seven species of free-ranging tropical pelagic seabirds. Fournal of Wildlife Diseases 34, 643-657.

Work, T. M. and Rameyer, R. A. (1997). Description and epizootiology of Babesia poelea n. sp. in brown boobies (Sula leucogaster (Boddaert)) on Sand Island, Johnston Atoll, Central Pacific. Fournal of Parasitology 83 734-738.

Yabsley, M. J. and Shock, B.C. (2013). Natural history of zoonotic Babesia: role of wildlife reservoirs. International fournal for Parasitology: Parasites and Wildlife 2, 18-31.

Yabsley, M. J., Greiner, E., Tseng, F. S., Garner, M. M., Nordhausen, R.W., Ziccardi, M.H., Borjesson, D. L. and Zabolotzky, S. (2009). Description of novel Babesia species and associated lesions from common murres (Uria aalge) from California. Fournal of Parasitology 95, 1183-1188. 